\title{
English: from British empire to corporate empire
}

\author{
Robert Phillipson \\ Department of International Language Studies and Computational Linguistics, Copenhagen Business School, Denmark \\ rp.isv@cbs.dk
}

\begin{abstract}
The article exemplifies and presents the characteristics of linguistic imperialism, linguistic capital accumulation following the same pattern as capitalist economic dominance. The text summarizes the way English was established in the colonial period. Many of the mechanisms of linguistic hierarchy have been maintained and intensified since then, as African and Indian scholarship demonstrates. Language plays a key role in education, the World Bank taking over where colonial regimes left off. Anglo-American efforts to maintain global English dominance have intensified since 1945 and are central to the present-day world 'order', as the postcolonial is subsumed under global empire, assisted by English linguistic neoimperialism. Some scholars who deny the existence of linguistic imperialism are reported on, and the complexity of language policy in European integration is demonstrated. The article concludes by setting out how the deceptive term 'lingua franca' needs to be challenged, and lists ways of exploring English as project, process, and product, setting out key research questions. The constraints of a short article only permit glimpses of a rapidly evolving scene, the visible top of the English iceberg.
\end{abstract}

Key words: Linguistic imperialism, empire, colonisation, linguistic neoimperialism, postcolonial education, linguistic capital, linguistic capital dispossession, lingua franca.

\section{Résumé}

L'article présente des exemples et les traits caractéristiques de l'impérialisme linguistique. L'accumulation du capital linguistique se produit de la même façon que la dominance capitaliste économique. Le texte fait le trajet de l'établissement de l'anglais dans l'époque coloniale. Plusieurs des mécanismes d'hiérarchisation linguistique ont été retenus et intensifiés depuis ce temps, ce que les chercheurs africains et indiens ont montré. La langue joue en rôle central dans l'enseignement; la Banque Mondiale continue les politiques de la période coloniale. Les efforts des AngloSaxons pour maintenir la dominance mondiale de l'anglais se sont accrus depuis 1945. Ils sont au cœur de «l'ordre» mondial actuel, tandis que la période postcoloniale se transforme en empire mondial, soutenu par le néoimperialisme linguistique de l'anglais. L'auteur fait l'analyse de quelques chercheurs qui nient l'existence de l'impérialisme linguistique, et présente la complexité des politiques de langue dans l'intégration de l'Europe. L'article se termine en expliquant comment le terme 'lingua franca' peut tromper et suggère qu'on doit faire une analyse de l'anglais comme projet, comme procédé et comme produit, en cernant plusieurs questions pour la recherche. Dans le trajet d'un petit article on ne peut que tracer les contours d'une actualité en plein changement, le sommet visible de l'iceberg anglais.

Mots-clé : Impérialisme linguistique, empire, colonisation, néo-impérialisme linguistique, éducation postcoloniale, linguistique capitale, lingua franca.

\section{Sammenfatning}

Artiklen præsenterer eksempler på sprogimperialisme og dens centrale træk. Sproglig kapitalakkumulation har samme mønster som kapitalistisk økonomisk dominans. Teksten giver en résumé af måden hvorpå engelsk blev konsolideret under koloniseringen. Mange af de mekanismer som udgør sproglig hierarkisering er blevet fastholdt og intensiveret siden hen, som forskning fra Afrika og Indien viser. Sprog spiller en central rolle i uddannelsessystemet. Verdensbanken har overtaget rollen som kolonistyren havde tidligere. Anglo-Amerikanske anstrengelser for at fastholde global engelsksproget dominans er blevet intensiveret siden 1945. De er centrale til den nuværende verdens 'orden', i takt med at det postkoloniale viger for global herredømme, som engelsk sproglig neoimperialisme fremmer. Fagfolk som afviser tilstedeværelsen af sprogimperialisme beskrives, der rapporteres om kompleksiteten af sprogpolitik i europæisk integration. Artiklen afsluttes med at bevise hvor bedragerisk begrebet 'lingua franca' er, og opsummerer hvordan man kan undersøge engelsk som projekt, som proces, og som produkt, herunder vigtige forskningsspørgsmål. Indenfor rammerne af en kort artikel er det kun glimt af en hurtigudviklende situation som kan gives, spidsen af den engelske isbjerg. 


\section{Table of contents}

1. Introduction

2. Patterns of colonisation, new and old

3. An English-dominant world system

4. Approaches to English linguistic imperialism

5. English linguistic imperialism moves to continental Europe?

6. Conclusion: exploring English as project, product and process

7. References

\section{Introduction}

There are countless books and journals being published in English on the history of the language and its assumed status as a 'global' or 'world' language. Likewise there are authoritative publications (encyclopaedia, handbooks) in English covering language policy, the ecology of languages, linguistic human rights, and threats to worldwide linguistic diversity. There is also a vast amount of sociolinguistic coverage of many languages in books and journals, including analyses of the current position of German and Spanish internationally, written in English. This information overload in English contrasts with the paucity of works in French and German on macrosociolinguistic issues such as language in globalisation or regional integration. One can conclude therefore that, even if there is significant coverage of language policy topics in Japanese, Spanish, Russian and other languages, scholarly publishing in the area of language policy, language and power, and linguistic imperialism confirms Anglo-American dominance. This dominance is partly due to economies of scale that reflect the size of the academic linguistic market, national (the USA) and international, but is due equally to the gate-keeping, hegemonic paradigms, and monolingual control that consolidate Anglophonic power in the information society and the knowledge economy. One revealing example: benchmarking handbooks on language and linguistics exclude Spanishlanguage references: 'the current English dominance within the geopolitics of knowledge is enhancing the symbolic capital of English and contributing to the erosion of linguistic diversity' (Mendieta, Phillipson and Skutnabb-Kangas 2006). How has this come about? Is the linguistic imperialism of the colonial age being perpetuated and reinforced in the contemporary world? Is the current pre-eminence of English the direct result of explicit and active US policy in the Americas since the formulation of the Monroe Doctrine of 1823, and similar policies in Europe throughout the $20^{\text {th }}$ century (Arnove 1982 , Smith 2003 ), and globally since $1945 ?$

I see linguistic imperialism as involving the following:

- it is a form of linguicism, a favouring of one language over others in ways that parallel societal structuring through racism, sexism and class: linguicism also serves to privilege users of the standard forms of the dominant language, those with convertible linguistic capital

- it is structural: more material resources and infrastructure are accorded to the dominant language than to others

- it is ideological: beliefs, attitudes, and imagery glorify the dominant language, stigmatize others, and rationalise the linguistic hierarchy

- the dominance is hegemonic, it is internalised and naturalised as being 'normal'

- linguistic imperialism interlocks with a structure of imperialism in culture, education, the media, communication, the economy, politics, and military activities 
- in essence it is about exploitation, injustice, inequality, and hierarchy that privileges those able to use the dominant language

- this entails unequal rights for speakers of different languages

- language use is often subtractive, proficiency in the imperial language and in learning it in education involving its consolidation at the expense of other languages

- linguistic imperialism is invariably contested and resisted.

This pattern of activities holds for the role of language in all empires, even if these inevitably display great variety over time and space (and some scholars do not see a pattern of linguistic imperialism, e.g. Ostler 2005). The Latin of the Roman empire left behind a massive legacy throughout Europe. Four European languages have major footholds on other continents - Spanish, Portuguese, French, and English - whereas political and military defeat diminished the impact of such languages as Dutch, German and Italian. A hierarchy of languages is integral to an imperial social order, discrimination by means of language - the acquisition and use of linguistic capital marking off privileged classes and groups from others, linguicism being entrenched structurally and ideologically.

Throughout the British Isles a monolingual ideology was propagated, with devastating effects, even if some Celtic languages have survived and are currently being revitalised. A monolingual ideology was exported to settler colonies in North America and Australasia, accompanying genocide of the local population. More differentiated policies were needed in exploitation colonies such as the Indian subcontinent and most African colonies. Since Nebrija, language has been the explicit handmaiden of empire, but one may need to distinguish between types of empire:

'formal' and 'informal' imperialism: the first meaning physical control or full-fledged colonial rule, while the second implied less direct but still powerful kinds of dominance, like Britain's $19^{\text {th }}$ century hegemony in Chile and Iran, or the USA's more recent role in much of central America. (Howe 2002: 24)

The notion of 'informal empire' can be traced back to Macaulay, the most eminent British historian of the mid- $19^{\text {th }}$ century, politician, and Indian administrator (Louis 1999: 5). Language played a much less important role in informal empires of the colonising type. In the current neoimperial world, English is increasingly in evidence. Plans to introduce English as a 'second official language' in Chile, Japan and Korea, and the policy of making the learning of English compulsory throughout education in China are symptomatic of this trend. The combined effect of the dovetailing of English with the British Empire, the strength of the American economy since the mid- $19^{\text {th }}$ century, and the global power structures put in place from 1945 (Bretton Woods, World Bank, IMF, WTO, United Nations etc), along with the imploding of a communist alternative, have all contributed significantly to the current pre-eminence of the language.

The historical record shows that this evolution was not left to chance: English has been (Phillipson 1992) and still is actively promoted, for instance by Gordon Brown on his first official visit to China and India. His Press Release of 17 January 2008 (http://www.number10.gov.uk/output/Page14289.asp) reveals a plan to make English the global language of 'choice' through strategic investments in English learning. The Murdoch-owned tabloid The Sun declared that Brown believes this will 'add a staggering £50billion a year to the UK economy by 2010 '. Imperialism has always been about profit. 
The corporate agenda that drives neoliberalism and the new imperialism (Harvey 2005) was precisely and presciently described in The Communist Manifesto by Marx and Engels in 1848. Bourgeois society

has set up that single unconscionable freedom - Free Trade. In a word, for exploitation, veiled by religious and political illusions, it has substituted naked, shameless, direct, brutal exploitation. [...] The need of a constantly expanding market for its products chases the bourgeoisie over the whole face of the globe. It must nestle everywhere, settle everywhere, establish connections everywhere. [...] In place of the old local and national seclusion and self-sufficiency, we have intercourse in every direction, a universal interdependence of nations. And as in material, so also in intellectual production. The intellectual creations of individual nations become common property. [...] It compels all nations, on pain of extinction, to adopt the bourgeois mode of production; it compels them to introduce what it calls civilization into their midst, i.e. to become bourgeois themselves. In one word, it creates a world after its own image. (reprinted in Mendel 1961: 15, 16, 17).

This is echoed by Bourdieu (2001: 84, translation RP):

'Globalisation' serves as a password, a watchword, while in effect it is the legitimatory mask of a policy aiming to universalise particular interests and the particular tradition of the economically and politically dominant powers, above all the United States, and to extend to the entire world the economic and cultural model that favours these powers most, while simultaneously presenting it as a norm, a requirement, and a fatality, a universal destiny, in such a manner as to obtain adherence or at the least, universal resignation.

The forms that globalisation has taken since the 1970s have consolidated the position of English in what Hardt and Negri (2000) see as Empire. Other dominant languages are of more regional significance, more localised variants of linguistic empire.

\section{Patterns of colonisation, new and old}

European expansionist policies in North America sometimes aimed at the assimilation of Native Americans rather than their extinction. European 'values' and Christianity were to 'civilise' the 'savages' to a capitalist economy and patriarchy, whether through European or indigenous languages. Literacy flourished in some of these, for instance Cherokee (Spring 1996), and Native Americans were introduced to Latin, Greek and Hebrew as well as English and more practically oriented knowledge. In 1838 the Board of Foreign Missions of the USA (then only 13 states, all separate colonies) articulated 'a belief in the manifest destiny of Anglo-Saxon culture to spread around the world' (ibid., 145). When the pressure on land became fiercer, more liberal policies were replaced by cultural and physical genocide. In education English generally became the sole language used. There are currently attempts to reverse this.

The policy of the USA transforming a diverse immigrant and indigenous population into monolingual English users was articulated by President Theodore Roosevelt in 1907: 'We have room for but one flag, the American flag... We have room for but one language here, and that is the 
English language... and we have room for but one sole loyalty and that is a loyalty to the American people.' (Italics added)

Education in US colonies functioned along similar lines. In the Philippines, there was an insistence on an exclusive use of English in education from 1898 to 1940: '... public education, specifically language and literature education during the American colonial period, was designed to directly support American colonialism. The combined power of the canon, curriculum, and pedagogy constituted the ideological strategies resulting in rationalising, naturalizing, and legitimizing myths about colonial relationships and realities.' (Martin 2002: 210).

Comparison of the British and French empires, drawing heavily on the analysis of scholars from the colonized world, leads to the conclusion that despite differences in the articulation of policies,

What the French and British empires had in common was:

- the low status of dominated languages, whether these were ignored or used in education,

- a very small proportion of the population in formal education, especially after the lowest classes,

- local traditions and educational practice being ignored,

- unsuitable education being given to Africans,

- $\quad$ an explicit policy of 'civilizing the natives',

- $\quad$ the master language being attributed civilizing properties. (Phillipson 1992: 128)

These broad generalizations are valid, even if policies were in fact worked out ad hoc in a wide variety of situations. In French colonies, the goal of producing a black French elite entailed using the educational content and methods of metropolitan France (Johnson 2005). In the British empire, 'English was the official vehicle and the magic formula to colonial élitedom' (Ngŭgĭ 1985: 115). 'By the opening decades of the twentieth century the crass objective of confining colonized people through inferior education had been dressed up with "scientific" justifications and permeated almost every corner of the Empire apart from South Asia' (Etherington 2005b: 269).

In India the situation was complex, due to its size and diversity, and since there were strong and ancient literacy traditions in the main languages. Education in these was widespread before the policy of promoting English was officialised. Three universities were founded in 1857, 14 by 1921, and 20 before independence in 1947. But westernization was in effect confined to elites. These have retained the role of the colonizers' language for postcolonial elite formation and privilege.

There are major differences in the way British language policy in India has been interpreted. At one extreme is the view that the decision to promote English and neglect Indian languages was 'largely a recognition of local Indian demands', and that the idea of colonialist imposition of English is a twentieth century 'myth' (Frykenberg 1999: 210). A more differentiated view is that the promotion of English reflected a firm belief in progress, 'English liberty, toleration and improvement', as articulated by the imperial spin doctor, Macaulay, who 'held arrogant but representative views on England's cultural ascendancy in the world and on what he believed to be the benevolent impact of British rule in India and elsewhere. The controversial Minute on Education, written in India in 1835, managed to reconcile British realpolitik and idealism in a way that left a lasting mark on subsequent interpretations of British rule' (Louis 1999: 5). At the other end of the spectrum is the analysis of an Indian who has lived through the entire post-independence period: 
The colonial language policy, therefore, was a part of the overall policy of governing the 'native subjects' in such a way that their minds would cease to be Indian. Language became an instrument for this purpose. It helped produce efficient and dedicated slaves who would be faithful to their masters and grateful to be slaves. The British rule consolidated itself mainly by dividing India into two classes: the loyal English educated Indians and the ignorant masses restricted to their 'vernaculars'. (Naik 2004: 254-5).

In British Africa until the 1950s, 90\% of educational work was in the hands of missionaries, from a range of European countries as well as the USA, working for dozens of different Christian denominations. Their primary goal was evangelisation, whether through English or the many African languages that missionaries codified, artificially because of colonial boundaries and linguistically and culturally uninformed selection practices. Christian missionaries remain active worldwide, often in the guise of teachers of English, posing a major ethical dilemma for the English teaching profession (Canagarajah and Wong forthcoming). Missionaries were generally looked down on by colonial administrators, and were often at odds with settlers and commercial interests, because they tended to disapprove of how the colonized were being treated (Etherington 2005a). There was in fact a tension throughout the history of the British Empire between the empirebuilders and critics of imperialism.

When colonies acquired political independence, a number of competing factors, supply and demand, 'aid' and dependence, have resulted in the continuation of the language policies of the colonial period till the present (Bamgbose 2006, Ricento 2000). In language education, five tenets have been of decisive influence since the 1960s, each of which is false (Phillipson 1992: 183-218): English is best taught monolingually (the monolingual fallacy); the ideal teacher of English is a native speaker (the native speaker fallacy); the earlier English is taught, the better the results (the early start fallacy); the more English is taught, the better the results (the maximum exposure fallacy); if other languages are used much, standards of English will drop (the subtractive fallacy).

The acquisition of linguistic capital in postcolonial societies is structurally constrained by linguistic market forces in such a way that 'choosing' English is contingent rather than free, since

European languages were imposed on Africans in the colonial period. African people as communities did not choose to learn those languages. [...]

Individual Africans do not necessarily choose to learn these languages (French, English, Portuguese). Since the language of instruction in almost all African countries is the language of the former colonial power, going to school does not leave any choice ...

Individuals who do not go to school, and therefore do not learn European languages, do not choose not to go to school. They do not have access to schooling (Rubagumya 2004: 134).

In the global village there are 'a few chiefs - very powerful economically and militarily - and a lot of powerless villagers. [...] The market has indeed replaced imperial armies, but one wonders whether the effect is any different. [...] It is therefore not the case that more English will lead to African global integration; the reverse is more likely.[...] Giving false hopes that everybody can have access to 'World English' is unethical' (ibid.: 136-139). 
The most significant source for funding for education in postcolonial states in the closing decades of the $20^{\text {th }}$ century was the World Bank, which has channelled funds toward the learning of the former colonial languages. World Bank policies filter through into the 'aid' agendas of the US and the British Overseas Development Administration (ODA), which favour a 'transition' from local languages to English:

...one needs to be cautious when the World Bank, which controls and influences the majority of aid packages to the third world, supports the transitional model. World Bank officials who visited South Africa in 1992 made it quite clear that additive bilingualism was not on the World Bank agenda and that funds would not be available to support such programmes. As mentioned earlier, USAID and ODA are heavily influenced by World Bank agendas, and the language education models they are supporting are consistently transitional ... a concrete example of just how powerfully persuasive Western aid agencies are in influencing policy' (Heugh 2003: 343, initially published in 1995).

The World Bank's real position ... encourages the consolidation of the imperial languages in Africa. ... the World Bank does not seem to regard the linguistic Africanisation of the whole of primary education as an effort that is worth its consideration. Its publication on strategies for stabilising and revitalising universities, for example makes absolutely no mention of the place of language at this tertiary level of African education (Mazrui 1997: 39).

A stratified education system that serves the interests of elites and neglects others is common. In India the 'biggest failure in 50 years of independence - its shameful neglect of primary education' (Malhoutra 1997: 152). This failure was to be addressed in the wake of the Jomtien ('Education for all') conference of 1991 through the use of foreign aid and loans, but projects such as India's District Primary Education Project were plagued with financial mismanagement and corruption (ibid.). Indian research indicates that 'Over the post-Independence years, English has become the single most important predictor of socio-economic mobility. [...] With the globalized economy, English education widens the discrepancy between the social classes' (Mohanty 2006: 268-9).

Educational policy may be changing towards a more active commitment to multilingualism (Agnihotri 2007).

Alexander (2006: 241) considers that in post-apartheid South Africa two factors determine current practices and attitudes in the relationship between language and power:

- the hierarchies of the linguistic market are largely determined by the mundane fact of economic and political, or military dominance

- the "colonised mind" (Ngŭgĭ wa Thiong'o 1994) of conquered peoples has often led to a failure on the part of their leadership to realise the power that is latent in the languages of the oppressed and of other subaltern strata or groups.

In South Africa 'politicians and even cultural leaders have never thought deeply about the language question. [...] an English-only or even an English-mainly policy might have some of the following effects:

- preventing the majority of the people from access to vital information and, therefore, from full participation in the democratic political process 
- undermining the self-confidence of L2-speakers and even more so of the vast majority for whom English is effectively a foreign language

- by the same token, smothering the creativity and spontaneity of people who are compelled to use a language of which they are not in full command

- at the economic and workplace levels, causing major avoidable blockages that have significant impacts on productivity and efficiency' (ibid.: 251).

Elsewhere in Africa the situation is comparable. Omoniyi (2003) in an article analysing why the Nigerian military government decreed in 1998 that French should be the 'second official language' of the country, describes the neglect of local languages as a 'rape on democracy' (2003: 23). The decision is a good example of push and pull factors working together in neoimperialism. The push of French economic interests in the region promoted through 'aid' (sixteen language attachés, support for 100 pilot schools, 6 colleges of education and 6 universities, 13 French language centres, ibid.: 20-21) combines with a Nigerian political wish (a pull) to subvert US interests and Commonwealth criticism of a military regime. Omoniyi refers to 'two Europhone cohorts that have outlived colonisation: Anglophone and Francophone Africa [...] they resuscitate and/or perpetuate colonial presence and rivalries, and neo-imperialist discourses in supposedly post-colonial times' (ibid.: 23).

It is also important to recall that TESOL (the Teaching of English to Speakers of Other Languages) itself is a significant export item - teaching materials, examinations, know-how, teachers et al - for the British and Americans, and a vital dimension of English linguistic neoimperialism. 'The English language teaching sector directly earns nearly $£ 1.3$ billion for the UK in invisible exports and our other education related exports earn up to $£ 10$ billion more' (Lord Neil Kinnock, Chair of the British Council, in the Foreword to Graddol 2006). The major publishing houses are now global. For instance, 'Pearson Education's international business has been growing rapidly in recent years, and we now have a presence in over 110 countries.' (http://www.pearson.com/index.cfm?pageid=18, accessed 15 January 2008). The website of Educational Testing Services of Princeton, NJ, which is responsible for the TOEFL test of English language proficiency, states: 'Our global mission goes far beyond testing. Our products and services enable opportunity worldwide by measuring knowledge and skills, promoting learning and performance, and supporting education and professional development for all people worldwide.' The ambivalent role of the TESOL enterprise is explored insightfully in a number of the contributions to Edge 2006.

US and UK interests and services are thus in symbiosis with education worldwide and with the evaluation of proficiency in English, with the assessment of linguistic capital. Those wishing for credentials in this linguistic market must invest in the form of 'global' English that examination boards profitably dispense. They administer what Bourdieu refers to as the sanctions of the (global) linguistic market.

\section{An English-dominant world system}

The archetypical aggressive British imperialist is Cecil Rhodes, who made a fortune in the diamond mines of South Africa, became the country's Prime Minister, and pushed northwards, founding countries which were named after him until they morphed into Zambia and Zimbabwe. He left his fortune in the form of Rhodes Scholarships and an Oxford institution, his primary goal being to 
influence key people from the dominions (Australia, Canada, New Zealand), India and the United States. Rhodes' purpose, as expressed in his first will (1877 - he died in 1902) was

- The extension of British rule throughout the world, the perfecting of a system of emigration from the United Kingdom and of colonization by British subjects of all lands wherein the means of livelihood are attainable by energy, labour and enterprise,

- the ultimate recovery of the United States of America as an integral part of the British Empire,

- the consolidation of the whole Empire, the inauguration of a system of Colonial Representation in the Imperial Parliament which may tend to weld together the disjointed members of the Empire,

- and finally the foundation of so great a power as to hereafter render wars impossible and promote the best interests of humanity. (Quigley 1981: 33, bullet structure added)

Only part of this scheme has been realized, but perhaps more than meets the eye. The constitutional bonds of Empire have been loosened in the establishment of a British Commonwealth of Nations, a network of Anglophonic 'global leaders' in the Rhodes mould. The American dog has waved the British tail since 1945, but with a 'special relationship' which can be traced through ChurchillRoosevelt, Thatcher-Reagan and Blair-Bush II. The strong links between the US and the UK were articulated by Churchill and Roosevelt in 1941 in the 'Atlantic Charter', which set out a policy for the post-war world, Churchill stressing in the House of Commons on 24 August 1941: '... the British Empire and the United States who, fortunately for the progress of mankind, happen to speak the same language and very largely think the same thoughts ...' (Morton 1943: 152). British ambivalence about its membership of the EU is partly due to the legacy of empire but more significantly to the competing tug of the political, military, cultural and linguistic links with the US. Some US think tanks envisage seeing the UK detached from 'Europe' and the creation of a transatlantic Anglosphere (see Phillipson 2008a).

US policies have become more visibly aggressive as the neoconservatives behind the Project for the New American Century, the Cheney-Wolfowitz-Rumsfeld doctrine, have been in power under Bush II. The overall strategy was analysed in Harper's Magazine in 2002 (cited in Harvey 2005: 80):

The plan is for the United States to rule the world. The overt theme is unilateralism, but it is ultimately a story of domination. It calls for the United States to maintain its overwhelming military superiority and prevent new rivals from rising up to challenge it on the world stage. It calls for dominion over friends and enemies alike. It says not that the United States must be more powerful, or most powerful, but that it must be absolutely powerful.

Condoleezza Rice regularly articulates this vision. The rhetoric of global 'leadership' was warmly embraced by Tony Blair: 'century upon century it has been the destiny of Britain to lead other nations. That should not be a destiny that is part of our history. It should be part of our future. We are a leader of nations or nothing.' (from a speech in 1997 cited in Le Monde Diplomatique, May 2007,16 .). This sentiment is scarcely compatible with the EU's principle of a foreign policy common to all member states.

It is perfectly logical for Tony Blair to opt for international banking after leaving British politics, since financial globalisation is central to the current economic world 'order'. Massive wealth has 
been consolidated in the hands of the top $1 \%$ of the world's population in the transition from a capitalism based on commodities to trading in financial services. The accumulation of this wealth is not territorially based (it depends on 'price-space' rather than 'physical space') and is intrinsically linked to the impoverishment and dispossession of the rest of the world's population, while privileging a small elite worldwide. While commodity capitalism evolved with pre-eminence for a number of 'large' languages, finance capital is symbiotically linked to the consolidation of English, and its acceptance by those who might earlier have insisted on parity for other languages such as French (Lysandrou \& Lysandrou 2003).

\section{Approaches to English linguistic imperialism}

The papers from a conference in Japan that contrasted various linguistic imperialisms are summed up in a Conclusion by one of the editors, Calvet (2005: 364), where he appears to state that linguistic imperialism on the part of the British and French is a thing of the past: in the case of English it is no longer needed, whereas in the case of French - in my interpretation of his comments - two issues need highlighting, The birth rate in former French colonies will influence the vitality of francophonie, which confirms Chaudenson's contention (2000) that the fate of French as a 'world' language will be decided in Africa rather than in Europe, where the battle has already been lost. Secondly, when French official discourse equates francophonie with diversity and its maintenance, this implies that it is pointless to continue preaching the superiority of French. While many of Calvet's other summary points are uncontroversial (distinguishing between linguistic nationalism and linguistic imperialism; different manifestations in particular historical periods), to suggest that French linguistic imperialism is dead and buried is false (the claim is in fact disputed by Miura Nobutaka in the same volume). There is abundant evidence that virtually all the criteria for linguistic imperialism that I list initially in this article apply to both French and English in the present world. How else can the massive efforts of the British Council to establish English in the post-communist world, or the French to put French rather than African languages on school timetables in former British colonies in Africa be understood (see the Nigerian example above)? How else can the activities of both governments to bid for and implement World Bank policies that favour European languages be understood? Calvet is a prolific author who operates with a schematic hierarchy of languages (based on de Swaan's theory of hypercentral, supercentral and other languages), and rightly exemplifies many of the variables (top-down, bottom-up, attitudinal) that influence the mosaic of languages. However, his analysis does not seriously engage with issues of power, or theorise contemporary linguistic imperialism, and I cannot detect any awareness of human rights principles (the statement 'Faire croire par exemple que l'on peut utiliser toutes les langues du monde pour l'éducation des enfants est une imposture néfaste', Calvet 2002, 207 is uninformed), nor of the significance of cultural and linguistic diversity for language ecology and biodiversity (Skutnabb-Kangas 2000).

Scholars who are sceptical about linguistic imperialism as an explanatory model for the way English has been consolidated worldwide tend to analyse matters as though there is a strict choice between (a) active US-UK promotion of English, supported by linguicist policies that favour it over and above other languages, and (b) colonised people and others actively wishing to learn English because of the doors, economic, social, political, and cultural, that it opens. Matters are summed up as though (a) involves imposition, whereas (b) is a 'free' choice (Kirkpatrick 2007: 35-7). This is a false dichotomy, the two elements in no way excluding each other. In addition, neither imposition nor freedom is context-free. Nor should (a) be seen as necessarily entailing the adoption of 'Anglo- 
cultural norms' and 'British and American culture', which is true, whereas (b) would not, which incorrectly ignores the lexico-grammatical substance embedded in the language, and the uses to which the language is put. Mono-causal explanations should be avoided. The norm is for there to be push and pull factors contributing to linguistic hegemony and hierarchy.

Kirkpatrick (ibid.) also accepts Fishman et al's analysis of 'Post-imperial English', which concludes that the strength of English in former British and American colonies is more due to such countries' engagement in the modern world economy rather than 'to any efforts derived from their colonial masters' (1996: 640). This analysis seems to ignore the fact that 'engagement in the modern world' means a western-dominated globalization agenda set by the transnational corporations and the IMF, and the U.S. military intervening, with or without a mandate from the United Nations, whenever 'vital interests' are at risk. World Bank, NAFTA, and World Trade Organization policies contribute to political instability, and provide less favourable conditions for education, democratization, cultural and linguistic diversity. English serves to consolidate the interests of the powerful globally and locally and to maintain an imbalanced exploitative world order, to disenfranchise speakers of other languages. A world polarized between a minority of English-using haves (whether as a first or second language) and a majority of have-nots is not likely to provide healthy conditions for people who speak languages other than English to flourish, so I have difficult in sharing Fishman's restrained optimism about linguistic power-sharing.

There is currently a considerable effort going into the documentation of English worldwide (see, for instance, Kachru, Kachru and Nelson 2006), its formal and functional diversity. Much of the description is celebratory, compounded by the use of such fuzzy terms as 'global' and 'international'. Halliday has elaborated an intriguing distinction between these:

English has become a world language in both senses of the term, international and global: international, as a medium of literary and other forms of cultural life in (mainly) countries of the former British Empire; global, as the co-genitor of the new technological age, the age of information. So those who are able to exploit it, whether to sell goods or ideas, wield a very considerable power. [...] It is important, I think, to distinguish these two aspects, the international and the global, even though they obviously overlap. English has been expanding along both trajectories: globally, as English; internationally, as Englishes. Both of these expansions involve what I have called semogenic strategies: ways of creating new meanings that are open-ended, like the various forms of metaphor, lexical and grammatical. But they differ. International English has expanded by becoming world Englishes, evolving so as to adapt to the meanings of other cultures. Global English has expanded - has become "global" - by taking over, or being taken over by, the new information technology, which means everything from email and the internet to mass media advertising, news reporting, and all the other forms of political and commercial propaganda. (Halliday 2006: 362-3)

Halliday's binary distinction is helpful, but the notion that 'world' Englishes are 'international' is invalid, since what is being referred to here is in fact local Englishes (Kenyan or Pakistani English). The terminology in this area is treacherous.

Halliday's focus on how adapting linguistic systems to new cultural demands can function locally and globally is grounded (not here explicitly) in a material and ideological understanding that is characteristic of Marxist approaches to language, which were refined in the $20^{\text {th }}$ century primarily 
by Gramsci and Bourdieu. The former British colony that has been most successfully transformed into a first-world economy is Singapore. Its language policy has downplayed tradition and ethnicity, and transformed citizens of diverse linguistic origins (mainly variants of Chinese and Indian languages) into users of English both in the public domain and increasingly even at home. This is a prime example of language management successfully achieving its goals through the creation of citizens who essentially identify with the materialism and consumerism that drive the global economy (Chew 2007). An authoritarian state aims at proficiency in British English and the ultimate elimination of the hybrid Singlish.

Brutt-Griffler, in a book entitled World English: A study of its development (reviewed in Phillipson 2004a) has argued that colonial education was more concerned to prevent colonial subjects from having access to English than with imposing the language. She sees World English as doing away with hierarchy among speech communities, non-Western nations taking equal part in the creation of the world econocultural system and its linguistic expression. At the same time she acknowledges that the US and UK dominate the world market and that World English is the dominant sociopolitical language form. Her attempt to explain the growth of English worldwide is therefore internally inconsistent, theoretically flawed, and based on argumentation that ignores the reality of the market forces, political, economic and military, that strengthen some languages at the expense of others locally and globally.

Some see a focus on the declared goals of US and UK policy and 'aid' investments as a conspiracy theory. This is simplistic and false. I have elsewhere, in an article that exposes the way Spolsky misrepresents my work (Phillipson 2007a), argued against this put-down. A conspiracy smear (it has nothing to do with theory) is often, as a study of neoliberal agendas and ideologies shows, 'the standard invalidating predicate to block tracking of strategic decisions' (McMurtry 2002: 17). What critical scholarship should be concerned with is 'the deeper question of the life-and-death principles of regulating value systems which connect across and explain social orders' (ibid.). This is the overall context within which uses of 'global' English need exploration.

Others see a strong emphasis on material and structural power as too deterministic, and as depriving those who vote with their feet for English of agency. I would claim that in any given context there are many push and pull factors that determine the way English linguistic hegemony is asserted. It is logical and comprehensible that English should be seen as desirable for the society and the individual, and involves agency, without endorsing a spurious use of 'choice'. There is no problem here provided that English is learned and used additively, as an extension of one's linguistic repertoire, but this is not the case when mother tongues are neglected, which is the case in many countries worldwide.

\section{English linguistic imperialism moves to continental Europe?}

The European context needs book-length treatment (Phillipson 2003) rather than a couple of paragraphs. In a recent survey article (2007b) I conclude that there is now European linguistic apartheid of three types: the exclusion of minority mother tongues from schools, public services and recognition; the de facto hierarchy of languages in the EU system, in internal and external communication; inequality between native speakers, particularly of English, and other Europeans, in international communication and especially in EU institutions. Unfortunately there are many obstacles to supranational, Europe-wide language policy formation. They can be enumerated in 
outline. Each of them impinges on English as both threat and promise. The length of the list makes it abundantly clear that the tension between English as an invasive, imperialist language and the promises that it holds out is not straightforward. What is unclear is what the outcomes of present trends will be:

- European history has led to different cosmologies in national linguistic cultures, making crosscultural dialogue treacherous;

- there are collisions of terminology (e.g. lingua franca, multilingualism, working language) in discourse (politics, media, business etc), and in distinct academic disciplines, as well as in different countries;

- overall responsibility for language policy in the EU is fragmented (Council of Ministers, Directorates for Education \& Culture, Translation, ...), and is ultimately an inter-governmental responsibility;

- there is a poor infrastructure nationally (except in Finland and Catalonia, perhaps in Sweden after legislation) and supranationally for addressing language policy issues, including a weak infrastructure in research;

- international coordination among national language bodies is in its infancy, and the processes for dialogue between scholars, interest groups, and policy-makers are fragile;

- language policy is politically untouchable at inter-governmental level;

- EU institutions are inconsistent in living up to ideals of multilingual equality (website, communications with member states) and in effect practise linguistic apartheid;

- the EU translation and interpretation services are impressive in many respects, but are detached from international research, and subject to an economic rationale, seeing themselves as a service function rather than policy-making;

- the language of EU written texts is increasingly under attack, even if the translation industry and translation technology are of increasing importance;

- the rhetoric of EU multilingualism and linguistic equality is seen as a charade by many;

- linguistic human rights are a recent development in international law, and do not constrain 'international' languages;

- criteria for guiding equitable supranational language policy are under-explored;

- journalistic coverage of language issues tends to be ill-informed;

- alternatives to market forces (the comparative advantage of English in the European linguistic market) and linguistic nationalism (e.g. Esperanto) are unexplored;

It is significant that both the EU and the Council of Europe now recommend some support for migrant languages, though there is still a long way to go before these are recognised in any member state as representing significant resources or involves them being seen as triggering rights. Ultimately language policy is a matter of power politics, linguistic nationalism, and economics.

When there are so many uncertainties currently, and when supranational national policy formation is stymied, market forces are allowed free rein. These all strengthen English nationally and supranationally. Thus when there are discussions about 'domain loss' in the Nordic languages, the central concept is inappropriate when it obscures the reality that it is the forces and agents of linguistic neoimperialism which are causing the linguistic capital dispossession of other languages. 


\section{Conclusion: exploring English as project, product and process}

The term lingua franca has been used in widely different senses in the past and is so still. I would claim that lingua franca is a pernicious, invidious term if the language in question is a first language for some people but for others a foreign language, such communication typically being asymmetrical. I would claim that it is a misleading term if the language is supposed to be neutral and disconnected from culture, from its uses and the purposes it serves. And that it is a false term for a language that is taught as a subject in general education, which English is worldwide. There is an ironic historical continuity in lingua franca being used as the term for the language of the medieval Crusaders battling with Islam, the Franks, and currently to refer to English as the language of the crusade of global corporatisation, marketed as 'freedom' and 'democracy'. In a lengthy Forum article to which seven scholars respond (Phillipson 2008b), 'Lingua franca or lingua frankensteinia? English in European integration and globalisation', in the journal World Englishes, I have explored misuse of the term in contemporary neoliberalism. The Frankenstein image refers to the agent behind the monster that gobbles up (speakers of) other languages.

One can attempt to bring together some of the many threads drawn on in this paper by seeing the lingua franca/frankensteinia project as entailing

- the imagining of a community, in the same way as polities are imagined (Anderson 1983), an English-using community without territorial or national boundaries;

- the invention of traditions (in the sense of Hobsbawm and Ranger 1983), customs, rituals and discourses that connect people through a merging of the language with hybrid agendas uniting the national, the European, the universal and global;

- ultimately the project reflects metaphysical choices and philosophical principles that underpin the type of community we wish to live in, the beliefs, values, and ethical principles that guide us, in a world that is currently dominated by neoliberalism, unsustainable consumerism, violence, and linguistic neoimperialism;

- our choices can either serve to maintain diversity, biological, cultural and linguistic ( $<\underline{w w w . t e r r a l i n g u a . o r g}>$ ) or to eliminate it, and current trends are alarming;

- all of which lead to visions of and for English, in Europe and elsewhere, and if these do not define lingua franca in such a way as to ensure equality and symmetry in intercultural communication, but are essentially one-sided promotion of English, the project tends to be more that of a lingua frankensteinia.

The lingua franca/frankensteinia process can be seen as entailing

- building communities of practice, of language use and language learning

- that people identify with at various levels

- which can be personal, interpersonal, intercultural, and subcultural

- in contexts of use, discourses, and domains 
- which conform to norms of linguistic behaviour that are institutionally (re-)inforced, legitimated and rationalised

- in societies that hierarchise by means of race, class, gender, and language

- leading to English being perceived as prestigious and 'normal', hence the feeling of native speakers that the language is universally relevant and usable, and the need for others to learn and use the language, in some cases additively, in others subtractively.

The lingua franca/frankensteinia product

- interlocks with economic/material systems, structures, institutions, and US empire

- is supported ideologically in cultural (re-)production and consumption

- in political, economic, military, media, academic and educational discourses

- through narratives of the 'story', the 'spread' of English, and language 'death'

- through metaphors of English as 'international', global, Godgiven, rich

- with the prestige code that of elites in the dominant Englishspeaking countries, and embedded in the lexis and syntax of the language.

Heuristic ways of clarifying whether the advance of English represents lingua franca rather than lingua frankensteinia trends would entail asking a series of questions, and relating each of them to English as project, process and product:

- Is the expansion and/or learning of English in any given context additive or subtractive?

- Is linguistic capital dispossession of national languages taking place?

- Is there a strengthening or a weakening of a balanced local language ecology?

- Where are our political and corporate leaders taking us in language policy?

- How can academics in English Studies contribute to public awareness and political change?

- If dominant norms are global, is English serving local needs or merely subordinating its users to the American empire project?

Empirical studies of such questions are needed before firmer conclusions can be drawn, in tandem with a refinement of the theoretical framework for understanding these changes in the global and local language ecology. 


\section{References}

Agnihotri, Rana K. (2007). "Identity and multilinguality: The case of India". In Amy B.M. Tsui and James W. Tollefson eds. Language policy, culture, and identity in Asian contexts. Mahwah: Lawrence Erlbaum, pp. 185-204.

Alexander, Neville (2006). "Socio-political factors in the evolution of language policy in post-Apartheid South Africa." In Martin Pütz, Joshua A. Fishman \& JoAnne Neff-van Aertselar eds. 'Along the routes to power'. Explorations of empowerment through language. Berlin: Mouton de Gruyter, pp. 241-260.

Anderson, Benedict (1983). Imagined communities. Reflections on the origin and spread of nationalism. London: Verso.

Arnove, R.F. ed. (1982). Philanthropy andf cultural imperialsm. The foundations at home and abroad. Bloomington: Indiana University Press.

Bamgbose, Ayo (2006). “A recurring decimal: English in language policy and planning”. In Braj B. Kachru, Yamuna Kachru and Cecil B. Nelson eds. The Handbook of World Englishes. Malden, MA and Oxford: Blackwell, pp. 645-660.

Bourdieu, Pierre (2001). Contre-feux 2. Pour un mouvement social européen. Paris: Raisons d'agir.

Brutt-Griffler, Janina (2003). World English: A Study of its Development. Clevedon: Multilingual Matters.

Calvet, Louis-Jean (2002). Le marché aux langues. Les effets linguistiques de la mondialisation. Paris : Plon.

Calvet, Louis-Jean (2005). "Conclusion". In Louis-Jean Calvet and Pascal Griolet eds. Impérialismes linguistiques, hier et aujourd'hui. Aix-en-Provence: INALCO/ÉDISUD, pp. 363-367.

Canagarajah, Suresh and Mary Wong eds. (forthcoming). Spiritual Dimensions and Dilemmas in English Language Teaching. Mahwah, NJ: Lawrence Erlbaum

Chaudenson, Robert (2000). Mondialisation: la langue française a-t-elle encore un avenir? Paris : Agence intergouvernementale de a francophonie.

Chew, Phyllis Ghim-lian (2007). "Remaking Singapore: Language, culture, and identity in a globalized world". In Amy B. M Tsui and James W. Tollefson eds. Language policy, culture, and identity in Asian contexts. Mahwah, NJ: Lawrence Erlbaum, pp.73-94.

Edge, Julian ed. (2006). (Re-)locating TESOL in an age of empire. Basingstoke: Palgrave Macmillan.

Etherington, Norman ed. 2005a. Missions and empire. Oxford: Oxford University Press.

Etherington, Norman ed. 2005b. Education and medicine. In Etherington (ed.) 2005a, 261-284.

Fishman, Joshua A., Andrew W. Conrad, Alma Rubal-Lopez eds. (1996). Post-imperial English. Status change in former British and American colonies, 1940-1990. Berlin/New York.

Frykenberg, Robert E. (1999). India to 1858. In Robin W. Winks ed. Historiography. Oxford: Oxford University Press, pp. 194-213. (The Oxford History of the British Empire, Volume 5.)

Graddol, David (2006). English next. Why global English may mean the end of English as a Foreign 
Language’. London: British Council.

Halliday, Michael A. K. (2006). Written language, standard language, global language. In Braj B. Kachru, Yamuna Kachru and Cecil B. Nelson eds. The Handbook of World Englishes. Malden, MA and Oxford: Blackwell, pp. 349-365.

Hardt, Michael \& Negri, Antonio (2000). Empire. Cambridge, MA: Harvard University Press.

Harvey, David (2005). The new imperialism. Oxford: Oxford University Press.

Heugh, Kathleen (2003). Language policy and democracy in South Africa. The prospects of equality within rights-based policy and planning. Stockholm: Centre for Research on Bilingualism, Stockholm University.

Hobsbawm, Eric and Terence Ranger eds. (1983). The invention of tradition. Cambridge: Cambridge University Press.

Howe, Stephen (2002). Empire, a very short introduction. Oxford: Oxford University Press.

Johnson, Nancy Kwang (2005). "Senegalese 'into Frenchmen'? The technology of nationalism in Senegal". In William Safran and Jean A. Laponce eds. Language, ethnic identity and the state. London \& New York; Routledge.

Kachru, Braj B., Yamuna Kachru and Cecil B. Nelson eds. (2006). The Handbook of World Englishes. Malden, MA and Oxford: Blackwell.

Kirkpatrick, Andy ed. (2002). Englishes in Asia: Communication, identity, power and education. Melbourne: Language Australia.

Louis, Wm. Roger (1999). "Introduction". In Robin W. Winks ed. Historiography. Oxford: Oxford University Press, pp. 1-42.

Malhoutra, Manmohan (1997). "Utopia revisited: a code of conduct for development". In Cees Hamelink, ed. Ethics and development: on making moral choices in development cooperation. Kampen: Kok, pp. 142158.

Martin, Isabel Pefianco (2002). Canon and pedagogy: the role of American colonial education in defining standards for Philippine literature. In Andy Kirkpatrick ed. World Englishes. Implications for international communication and English Language Teaching. Cambridge: Cambridge University Press, pp. 2101-212.

Mazrui, Alamin (1997). "The World Bank, the language question and the future of African education". Race and Class 38/3: 35-48.

McMurtry, John (2002). Value wars. The global market versus the life economy. London: Pluto.

Mendel, Arthur P. ed. (1961). Essential works of Marxism, New York: Bantam.

Mendieta, Eduardo, Robert Phillipson and Tove Skutnabb-Kangas (2006). "English in the geopolitics of knowledge". Revista Canaria de Estudios Ingleses 53: 15-26.

Mohanty, Ajit (2006). "Multilingualism and predicaments of education in India". In Ofelia García, Tove Skutnabb-Kangas and María E. Torres-Guzmán eds. Imagining multilingual schools. Languages in 
education and glocalization. Clevedon: Multilingual Matters, pp. 262-283.

Morton, H.V. (1943). Atlantic meeting. London: Methuen.

Naik, Chitra (2004). "India's language policy in an uncertain century". In Patrick V. Dias ed. Multiple languages, literacies and technologies. New Delhi: Books for Change, pp. 246-263.

Ngŭgĭ wa Thiongø’o (1985). "The language of African literature”. New Left Review, April-June 1985: 10927.

Ngŭgĭ wa Thiong'o (1994). Decolonising the mind. The politics of language in African literature. London: James Currey.

Omoniyi, Tope (2003). "Language ideology and politics. A critical appraisal of French as a second language in Nigeria". In Sinfree Makoni and Ulrike H. Meinhof eds. Africa and applied linguistics, AILA Review 16. Amsterdam: John Benjamins, pp.13-23.

Ostler, Nicholas (2005). Empires of the word. A language history of the world. London: HarperCollins.

Phillipson, Robert (1992). Linguistic imperialism. Oxford: Oxford University Press.

Phillipson, Robert (1999). "Voice in global English: unheard chords in Crystal loud and clear". Review article on 'English as a global language' by David Crystal. Applied Linguistics 20/2: 288-299.

Phillipson, Robert (2000). "English in the new world order. Variations on a theme of linguistic imperialism and 'world' English". In Thomas Ricento ed. Ideology, politics and language policies: Focus on English. Amsterdam: John Benjamins, pp. 87-106.

Phillipson, Robert (2003). English-only Europe? Challenging language policy. London: Routledge.

Phillipson, Robert (2004). "Review article, English in globalization: three approaches (books by de Swaan, Block and Cameron, and Brutt-Griffler)". Journal of Language, Identity, and Education, Vol. 3/1: 73-84.

Phillipson, Robert (2006). "English, a cuckoo in the European higher education nest of languages?" European Journal of English Studies, 10/1: 13-32.

Phillipson, Robert (2007a). "Linguistic imperialism: a conspiracy, or a conspiracy of silence?". Language policy, 6/3-4: 377-383.

Phillipson, Robert (2007b). “English in Europe: threat or promise?” In . Máiréad Nic Craith ed. Language, power and identity politics. Basingstoke: Palgrave Macmillan, pp. 65-82.

Phillipson, Robert (2008a). "The linguistic imperialism of neoliberal empire". Critical Inquiry in Language Studies 5/1: 1-43.

Phillipson, Robert (2008b). "Lingua franca or lingua frankensteinia? English in European integration and globalisation". World Englishes, 27/2: 250-284.

Pieterse, Jan N. (2004). Globalization or empire. New York and London: Routledge.

Quigley, Carroll (1981). The Anglo-American establishment. From Rhodes to Cliveden. New York: Books in focus. 
Ricento, Thomas ed. (2000). Ideology, politics and language policies: Focus on English. Amsterdam: John Benjamins.

Ricento, Thomas ed. (2006). An introduction to language policy. Theory and method. Oxford: Blackwell.

Rothkopf, David (1997). “In praise of cultural imperialism”. Foreign policy, 38-53.

Rubagumya, Casmir (2004). "English in Africa and the emergence of Afro-Saxons: globalization or marginalization". In Mike Baynham, Alice Deignan and Goodith White eds. Applied linguistics at the interface. London: Equinox, for the British Association of Applied Linguistics, pp. 133-144.

Skutnabb-Kangas, Tove (2000). Linguistic genocide in education - or worldwide diversity and human rights? Mahwah, NJ: Lawrence Erlbaum.

Smith, Neil (2003). American empire. Roosevelt's geographer and the prelude to globalization. Berkeley and Los Angeles, CA: University of California Press.

Spring, Joel (1996). The cultural transformation of a Native American family and its tribe 1763-1995. Mahwah, NJ: Lawrence Erlbaum. 